\title{
Evaluation of lodine and Water Co-adsorption on Silver-Functionalized Aerogel
}

\section{Fuel Cycle Research \& Development}

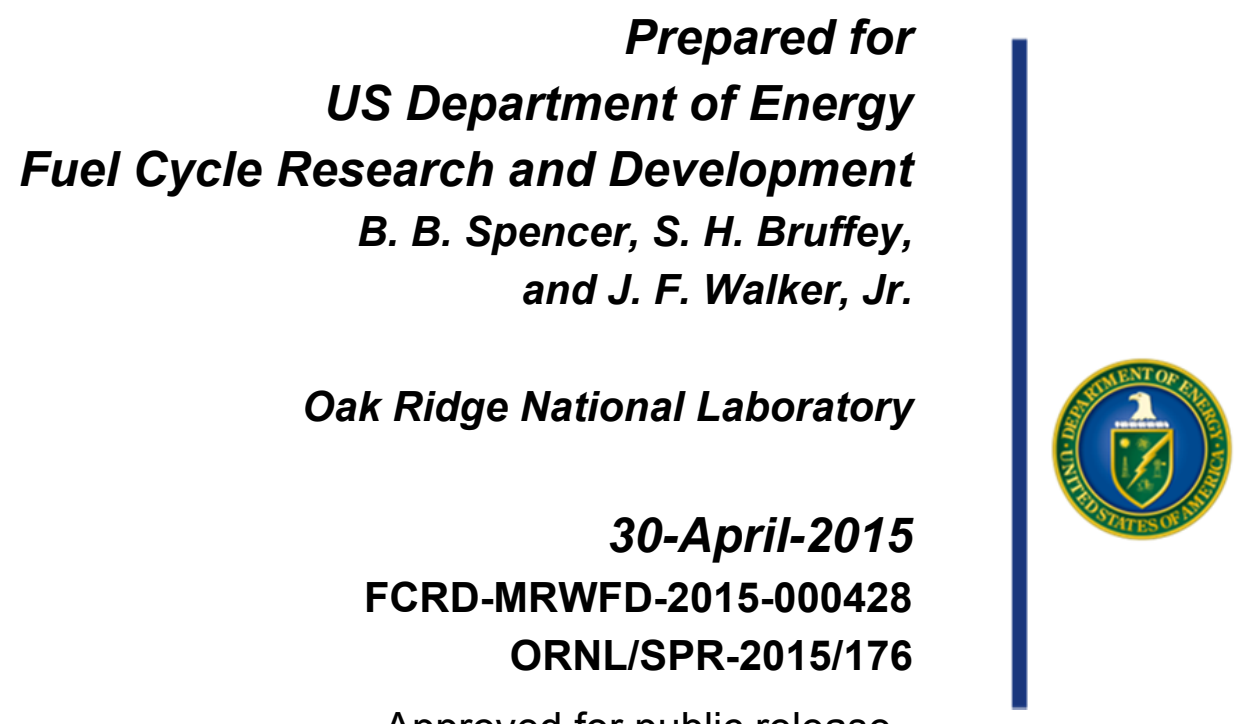

Approved for public release.

Distribution is unlimited. 


\title{
DOCUMENT AVAILABILITY
}

Reports produced after January 1, 1996, are generally available free via US Department of Energy (DOE) SciTech Connect.

Website http://www.osti.gov/scitech/

Reports produced before January 1, 1996, may be purchased by members of the public from the following source:

\author{
National Technical Information Service \\ 5285 Port Royal Road \\ Springfield, VA 22161 \\ Telephone 703-605-6000 (1-800-553-6847) \\ TDD 703-487-4639 \\ Fax 703-605-6900 \\ E-mail info@ntis.gov \\ Website http://www.ntis.gov/help/ordermethods.aspx
}

Reports are available to DOE employees, DOE contractors, Energy Technology Data Exchange representatives, and International Nuclear Information System representatives from the following source:

Office of Scientific and Technical Information

PO Box 62

Oak Ridge, TN 37831

Telephone 865-576-8401

Fax 865-576-5728

E-mail reports@osti.gov

Website http://www.osti.gov/contact.html

This report was prepared as an account of work sponsored by an
agency of the United States Government. Neither the United States
Government nor any agency thereof, nor any of their employees,
makes any warranty, express or implied, or assumes any legal liability
or responsibility for the accuracy, completeness, or usefulness of any
information, apparatus, product, or process disclosed, or represents
that its use would not infringe privately owned rights. Reference herein
to any specific commercial product, process, or service by trade name,
trademark, manufacturer, or otherwise, does not necessarily constitute
or imply its endorsement, recommendation, or favoring by the United
States Government or any agency thereof. The views and opinions of
authors expressed herein do not necessarily state or reflect those of
the United States Government or any agency thereof.




\section{SUMMARY}

The co-adsorption of iodine and water on silver-functionalized silica aerogel was evaluated using research quantities of the aerogel prepared at Pacific Northwest National Laboratory. A macro thermogravimetric analyzer was used to measure weight changes in a thin bed of the aerogel as air streams containing moisture and/or iodine flowed through the bed. The total gas flow in all tests was adjusted to achieve a velocity of $10 \mathrm{~m} / \mathrm{min}$ through the bed.

Initial heating of the aerogel sample to $150^{\circ} \mathrm{C}$ in dry air (dew point $<-60^{\circ} \mathrm{C}$ ) resulted in weight loss on the order of $1 \mathrm{wt} \%$. Because subsequent phases of the tests indicated that the aerogel did not sorb water, the weight loss was speculated to be caused by volatilization of material that may have been used in the manufacture of the aerogel. Follow-on tests are recommended to ascertain if the aerogel sorbs water at low temperatures, such as $25^{\circ} \mathrm{C}$ - this would help to determine if a manufacturing reagent is volatilized when raising the sample to iodine sorption temperatures $\left(\right.$ i.e., $\left.150^{\circ} \mathrm{C}\right)$. Alternatively, the off-gas released upon heating could be condensed and analyzed.

In tests using humidified air streams with dew points between $-60^{\circ} \mathrm{C}$ and $+10^{\circ} \mathrm{C}$, the aerogel did not adsorb water at test temperatures of either $75^{\circ} \mathrm{C}$ or $150^{\circ} \mathrm{C}$. Because water alone was not adsorbed, tests were performed to ascertain if iodine sorption varied between cases when nearly no water was present in the gas stream and when water was present.

In one experiment, the gas stream consisted of dry air (dew point $<-60^{\circ} \mathrm{C}$ ) with an iodine concentration of $50 \mathrm{ppmv}$. In the other experiment, the gas stream consisted of air with a water dew point of $0^{\circ} \mathrm{C}$ and an iodine concentration of $50 \mathrm{ppmv}$. The ultimate weight gain was nearly the same in both experiments and was presumed to be due entirely to adsorption of iodine. However, a reduced rate of iodine uptake is indicated when water vapor is present. The reason for this is unclear. In both cases, purging the sample with dry, iodine-free air resulted in some weight loss $(\sim 2 \mathrm{wt} \%)$. It is recommended that the gas phase chemistry of the iodine-water system be reviewed to ascertain if iodine species that are less reactive with silver than molecular iodine are present; this could explain the reduced sorption rates when water is present. Further evaluation of the desorption is recommended, especially to determine how raising the temperature would affect desorption. 


\section{CONTENTS}

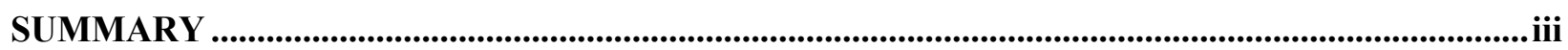

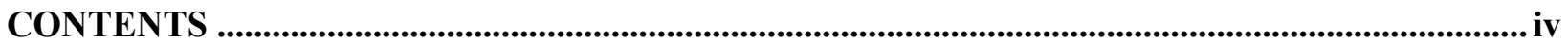

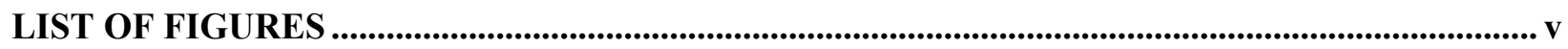

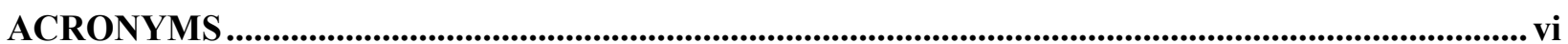

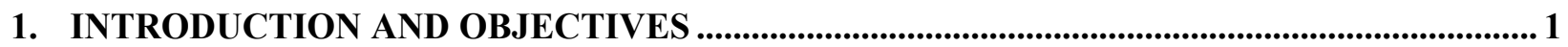

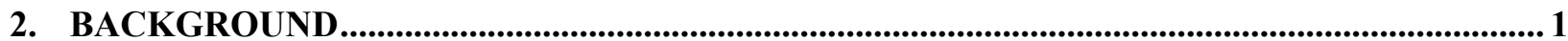

3. EXPERIMENTAL EQUIPMENT AND PLANNED CONDUCT OF EXPERIMENTS ............... 1

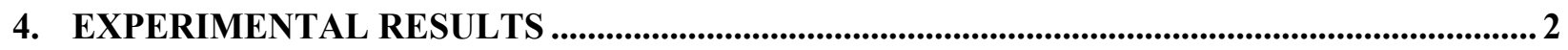

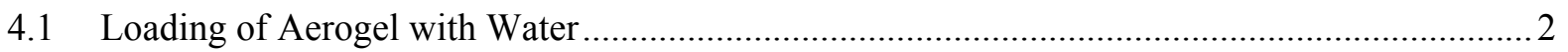

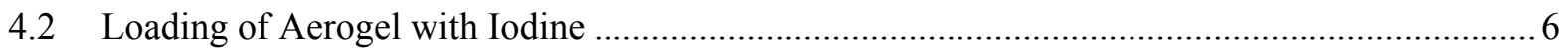

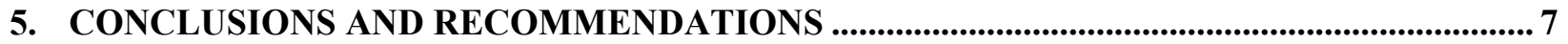

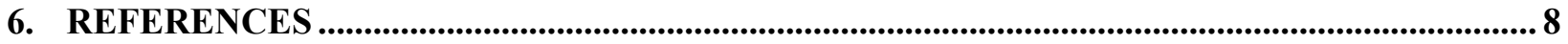




\section{LIST OF FIGURES}

Figure $\quad$ Page

1. Change in aerogel mass with varying water content of the feed gas-Run FY15-013 at $145^{\circ} \mathrm{C} \ldots \ldots \ldots \ldots . . . . .3$

2. Variations in measured sample weight compared with fluctuations in balance temperature-

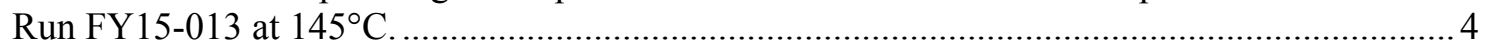

3. Change in aerogel mass with varying water content of the feed gas-Run FY15-014 at $75^{\circ} \mathrm{C}$............. 5

4. Change in aerogel mass with varying water content of the feed gas-Run FY15-015 at $145^{\circ} \mathrm{C}$. .......... 6

5. Fractional change in aerogel weight during iodine uptake from air streams containing $50 \mathrm{ppmv}$

$\mathrm{I}_{2}$ and water dew points of either $<-60^{\circ} \mathrm{C}$ or $0^{\circ} \mathrm{C}$. 


\section{ACRONYMS}

$\mathrm{AgZ} \quad$ silver mordenite

ORNL Oak Ridge National Laboratory

PNNL Pacific Northwest National Laboratory

TGA thermogravimetric analyzer 


\section{Evaluation of lodine and Water Co-adsorption on Silver-Functionalized Aerogel}

\section{INTRODUCTION AND OBJECTIVES}

Silver-functionalized silica aerogel is being investigated as a sorbent to remove radio-iodine from the offgas streams of nuclear fuel processing facilities. As with the previously studied silver mordenite (AgZ), there are questions regarding the co-adsorption of water (in actual practice, tritiated water) with the iodine. $^{1}$

The objectives of the present tests were to determine the amount of water that adsorbs or co-adsorbs with the iodine on the aerogel, and to ascertain whether the presence of water in the off-gas stream inhibits or enhances the sorption of iodine on the aerogel.

\section{BACKGROUND}

The need to control emissions of gaseous radionuclides to the atmosphere during nuclear fuel recycling is widely recognized. Gaseous radionuclides can partition to off-gas streams emanating from various individual processes used in a recycling plant, such as the mechanical head end (shear), tritium pretreatment, fuel dissolver, vessel vents, cell ventilation, and melting operations. Tritium pretreatment releases the tritium from the fuel, along with small fractions of iodine and noble gases. The tritium is rapidly converted to tritiated water, which may be recovered with molecular sieves, while the iodine may be recovered using AgZ. In traditional recycling plants, the bulk of the volatile fission products (i.e., $\mathrm{Kr}$, $\mathrm{Xe}, \mathrm{I}$, and ${ }^{3} \mathrm{H}$ ) is released during the dissolution process. Dissolver off-gas is also accompanied by nitrogen oxides and nitric acid vapors. Because of the corrosive nature of these gases and vapors, it has been proposed that $\mathrm{AgZ}$ may be used for iodine removal, because mordenite is resistant to degradation by these oxy-acids. The AgZ has been shown to co-adsorb significant amounts of water from a gas phase, although methods to reduce or to prevent co-contamination of the (tritiated) water and iodine with one another have been devised and demonstrated. ${ }^{1}$

Functionalized silica aerogels are under development as potential alternative iodine sorbents. Their high selectivity and high sorption capacity for iodine make aerogels an attractive option. In addition, high temperature consolidation of iodine-loaded silica aerogels can produce a durable $\mathrm{SiO}_{2}$-based waste form. ${ }^{2}$ Research quantities of the aerogel have been prepared at Pacific Northwest National Laboratory (PNNL) and provided to Oak Ridge National Laboratory (ORNL) for evaluation. ${ }^{3}$

\section{EXPERIMENTAL EQUIPMENT AND PLANNED CONDUCT OF EXPERIMENTS}

An existing macro thermogravimetric analyzer (TGA) and gas feed system, previously described in detail, ${ }^{4,5}$ were used to conduct the sorption tests. Inside a temperature controlled oven, a thin bed of aerogel was suspended from a balance on a porous frit and was placed within a gas flow chimney. Process gas composition was adjusted by adding water, iodine, or a combination of water and iodine to dry air (dew point $<-60^{\circ} \mathrm{C}$ ). The total gas flow rate was set to achieve a superficial gas velocity of $10 \mathrm{~m} / \mathrm{min}$ within the gas chimney at the testing temperature. In each test the mass of the aerogel sample was measured and recorded every minute until the sample equilibrated with the feed gas.

Experiments were conducted in three phases: (1) uptake of water from air having dew points of $-10^{\circ} \mathrm{C}$, $0^{\circ} \mathrm{C}, 5^{\circ} \mathrm{C}$, and $10^{\circ} \mathrm{C}$, but with no iodine present; (2) uptake of iodine from dry air (dew point $<-60^{\circ} \mathrm{C}$ ) 
containing 50 ppmv iodine $\left(\mathrm{I}_{2}\right)$; and (3) simultaneous uptake of iodine and water from air containing 50 ppmv $\mathrm{I}_{2}$ and having a water dew point of $0^{\circ} \mathrm{C}$.

\section{EXPERIMENTAL RESULTS}

\subsection{Loading of Aerogel with Water}

Three tests of water loading on the aerogel were performed. In the first test (Run FY15-013), $2.136 \mathrm{~g}$ of aerogel at room temperature was loaded into the macro-TGA, which had been preheated to $145^{\circ} \mathrm{C}$. Fig. 1 shows a change in the measured mass of the aerogel sample as the water content of the feed gas was changed (dew point targets are indicated by boxes and arrows, and partial pressure of water vapor in the gas phase, inferred from instrumentation, is plotted against the scale on the right side). Following the events in the figure, initially there was a weight loss of about $1.2 \mathrm{wt} \%$ as the sample temperature increased from about $23^{\circ} \mathrm{C}$ to $145^{\circ} \mathrm{C}$ in dry air (dew point $<-60^{\circ} \mathrm{C}$ ). Initially this was thought to be caused by water loss. Under stable conditions the data indicate a measurement error of about \pm 0.1 points (e.g., $-1.2 \mathrm{wt} \% \pm 0.1 \%$ ). Increasing the dew point of air to $-10^{\circ} \mathrm{C}$ did not significantly increase the sample weight. Further increase of the air dew point to $0^{\circ} \mathrm{C}$ appeared to cause a very small increase, but not larger than the estimated error in the measurement. Further increase to a target dew point of $5^{\circ} \mathrm{C}$ stalled until the water bubbler was heated to overcome evaporative cooling; then the dew point of $5^{\circ} \mathrm{C}$ was attained. Although there appeared to be some increase in sample weight as the higher dew point was achieved, the sample mass then decreased to near its value that prevailed when the dew point was $<-60^{\circ} \mathrm{C}$. In previous campaigns, it was observed that the macro-TGA balance reading can be affected by the temperature of the balance. Fig. 2 shows the same sample weight readings shown in Fig. 1 plotted with the measured balance temperature. It appears that the mass reading on the balance is affected by the temperature of the balance. Overall, the aerogel did not exhibit behavior indicative of adsorption equilibria dependent on water concentration in the gas phase. 


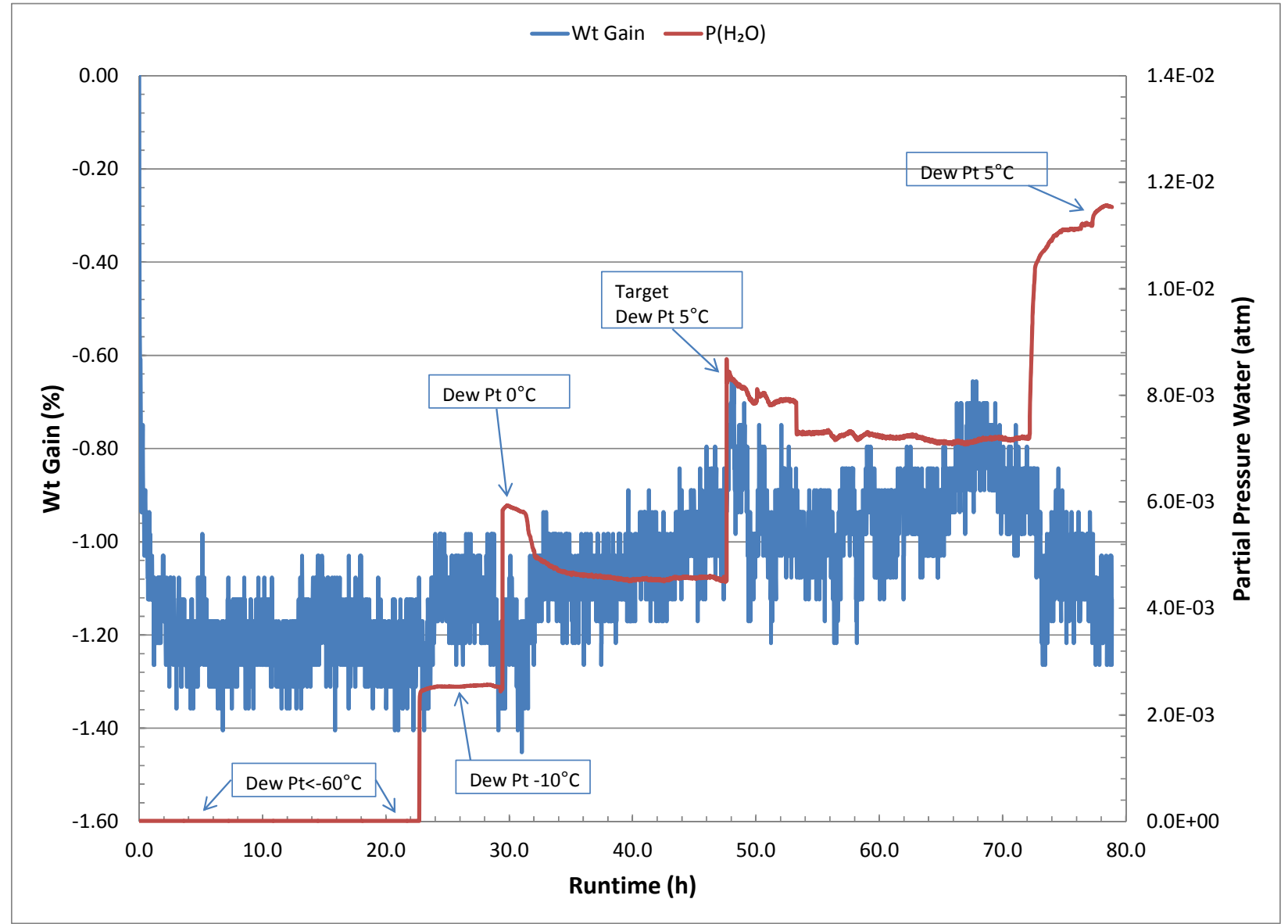

Fig. 1. Change in aerogel mass with varying water content of the feed gas-Run FY15-013 at $145^{\circ} \mathrm{C}$. 


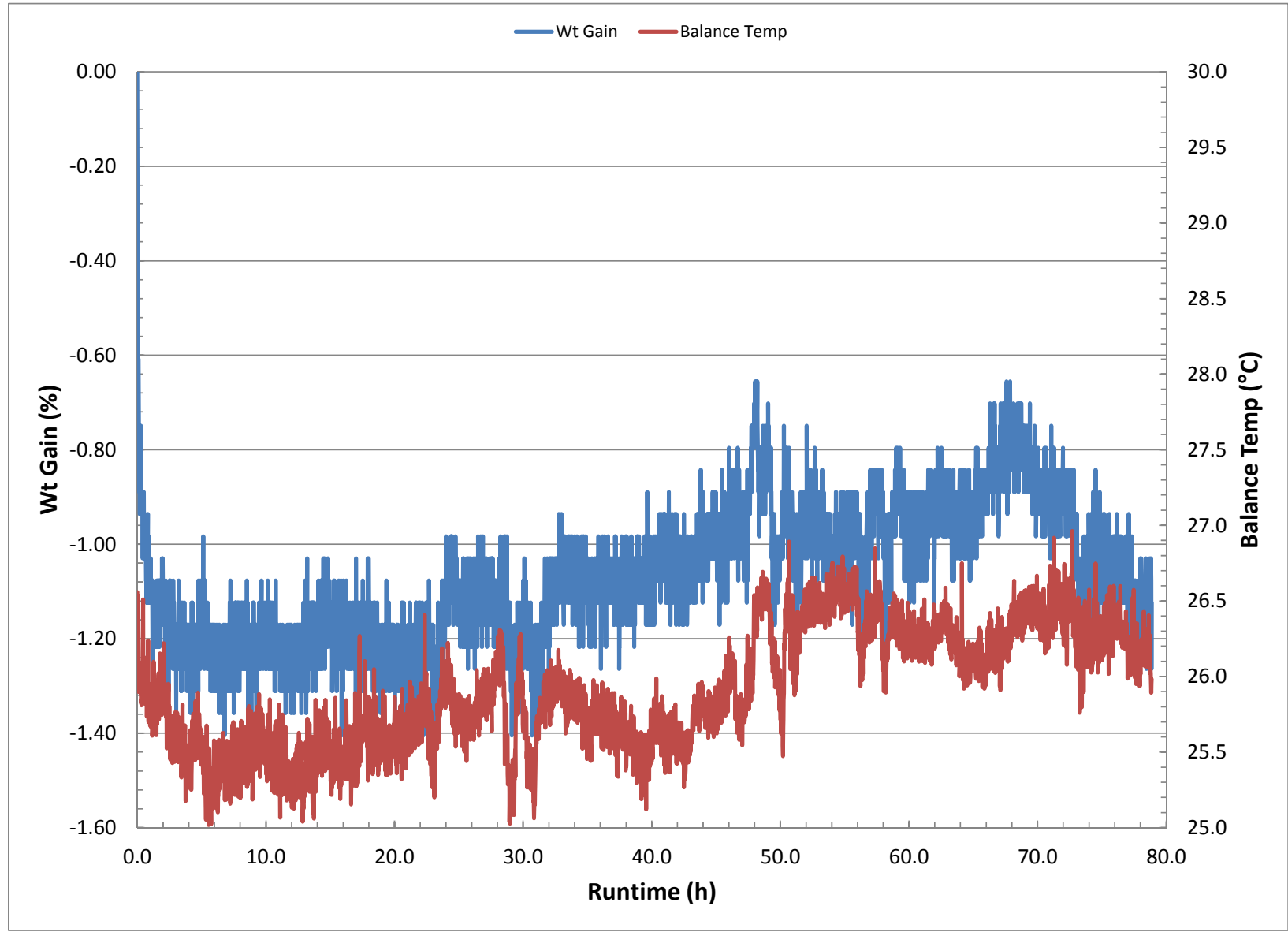

Fig. 2. Variations in measured sample weight compared with fluctuations in balance temperatureRun FY15-013 at $145^{\circ} \mathrm{C}$.

The second test (Run FY15-014) used the same sample of aerogel but was initiated by decreasing the furnace temperature to $75^{\circ} \mathrm{C}$ and feeding dry air to the sample. It was presumed that use of a lower temperature would permit water to sorb more readily on the sample if there were a tendency for the sample to adsorb water. As shown in Fig. 3, there was a rapid rise in the measured weight of the sample, although the feed gas contained essentially no water. This may have been an artifact of the changes in gas properties that affect the buoyancy of the sample or the frictional drag on the sample caused by the upward flow of the gas (density, viscosity, etc.). Although the weight changes are greater than the estimated measurement error, there is no correlation between water concentration in the gas phase and weight of the sample. Upon checking, researchers found that large changes in the balance temperature occurred - thus the transients in the sample weight could have been caused by temperature changes. 


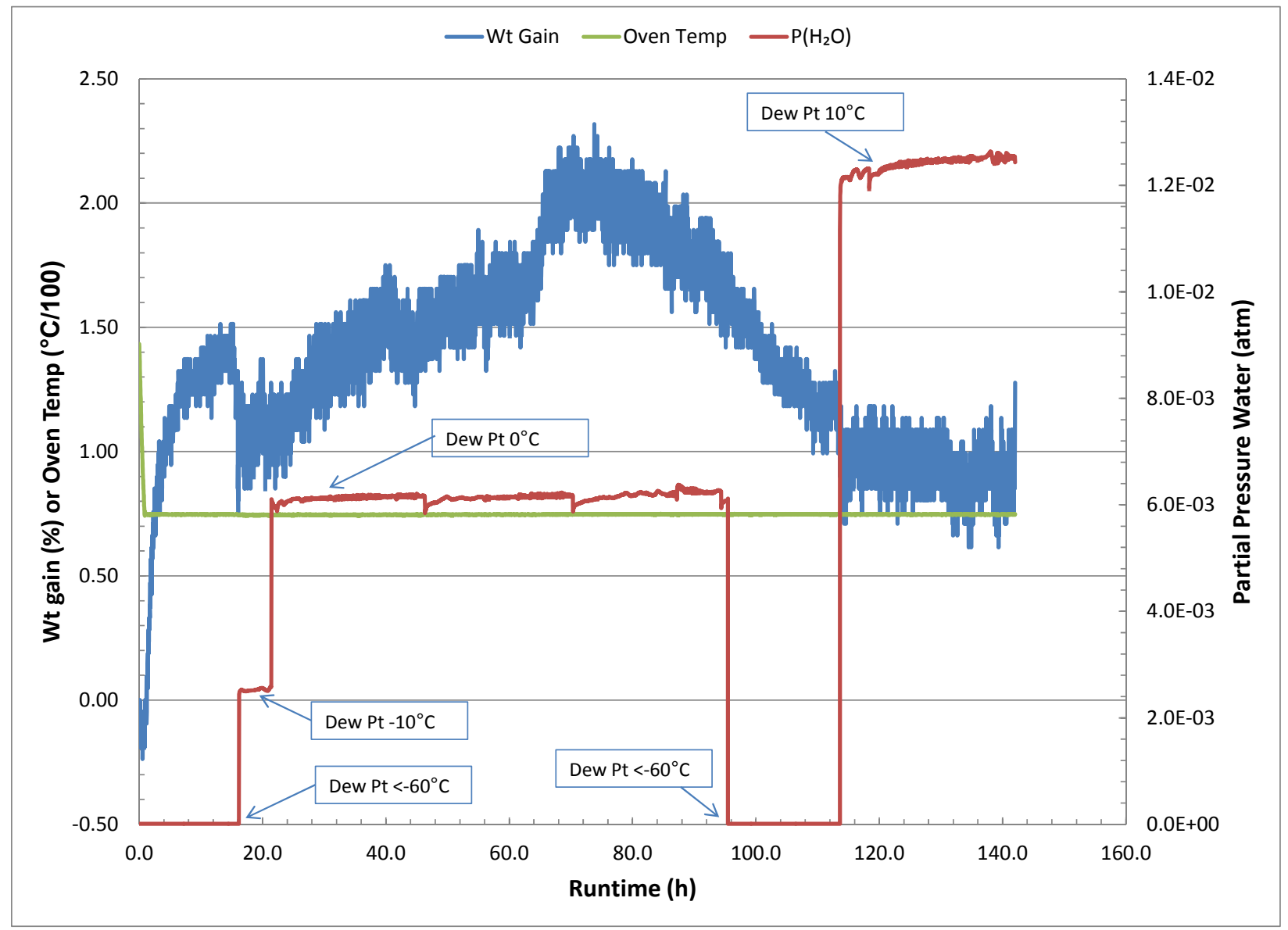

Fig. 3. Change in aerogel mass with varying water content of the feed gas-Run FY15-014 at $75^{\circ} \mathrm{C}$.

The third test (Run FY15-015) was performed to obtain additional data on the sorption/desorption of water on the aerogel at a temperature of $145^{\circ} \mathrm{C}$. A $1.593 \mathrm{~g}$ sample of aerogel was loaded into the macroTGA, which had been preheated to $145^{\circ} \mathrm{C}$. The sample was allowed to equilibrate at that temperature for $19.5 \mathrm{~h}$, at which time the measured weight was $1.554 \mathrm{~g}$ (an apparent loss of $2.5 \mathrm{wt} \%$ ). The gas feed was changed in one step from dry air (dew point $<-60^{\circ} \mathrm{C}$ ) to air having a dew point of $-5^{\circ} \mathrm{C}$ (runtime defined at that point was $0 \mathrm{~h}$ ). Fig. 4 shows that there was no significant weight gain during more than $22 \mathrm{~h}$ of exposure to the moist air stream. As a further check, the air feed was returned to dry air (dew point $<-60^{\circ} \mathrm{C}$ ), and no loss in weight was measured over a $3 \mathrm{~h}$ observation period (see Fig. 4).

The data indicate that the aerogel does not adsorb significant amounts of water from humid air. The fact that there is an initial weight loss when the sample is subjected to elevated temperature suggests that the aerogel outgasses an unknown material - perhaps an organic material used as part of the functionalization of the surface in preparation for the silver deposition. 


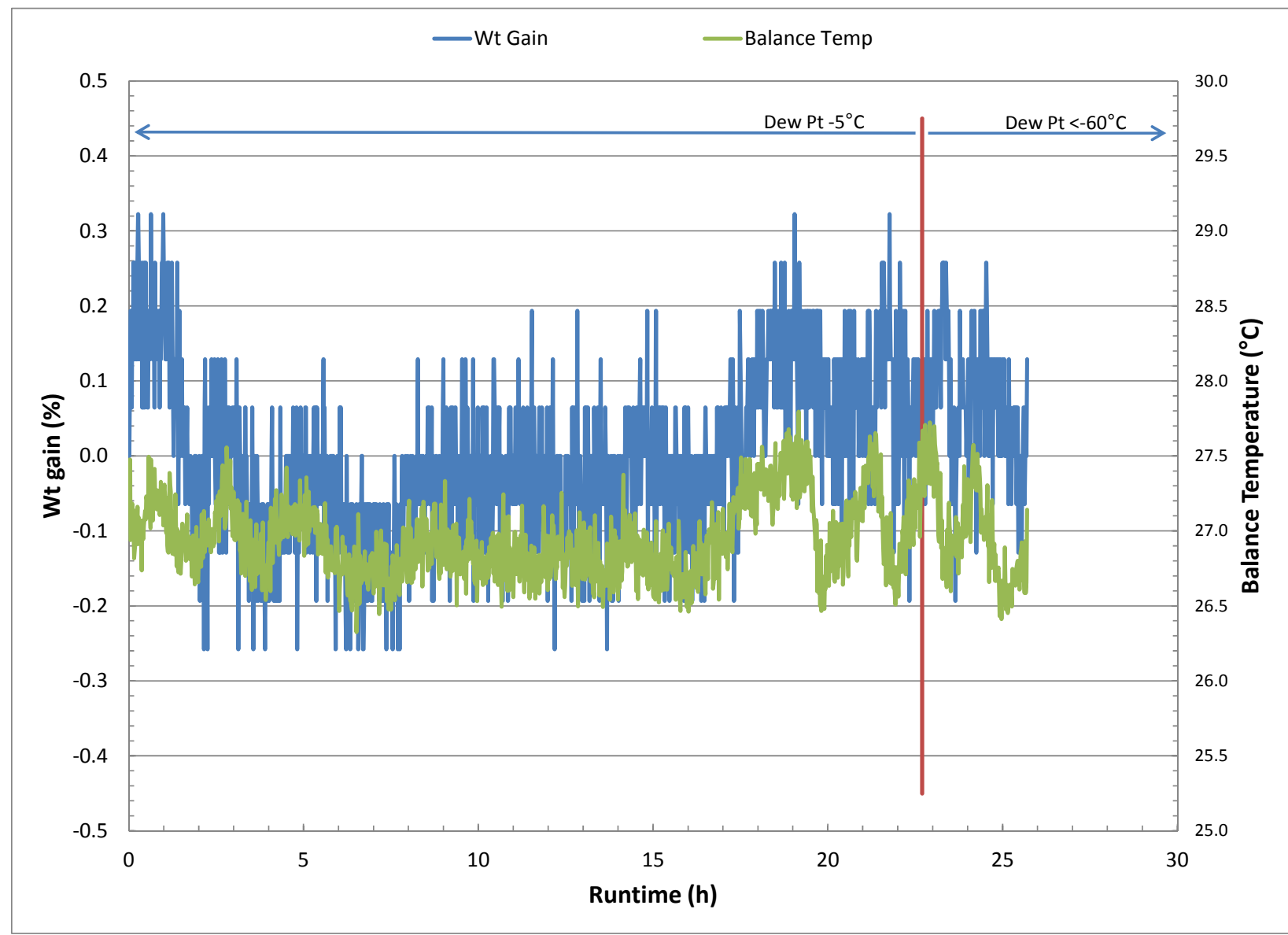

Fig. 4. Change in aerogel mass with varying water content of the feed gas-Run FY15-015 at $145^{\circ} \mathrm{C}$.

\subsection{Loading of Aerogel with lodine}

The second and third phase tests consisted of loading the aerogel with iodine from either dry air or humid air, respectively. Duration of the tests was significant because prototypical iodine concentrations were $50 \mathrm{ppmv}$, and the aerogel has a high iodine capacity. In both thin bed experiments, the solid sample was maintained at an operating temperature of $145^{\circ} \mathrm{C}$ (slightly lower than the $150^{\circ} \mathrm{C}$ set point of the oven). The gas flow rate was adjusted in each experiment to achieve a gas velocity of $10 \mathrm{~m} / \mathrm{min}$ through the bed.

In the second phase test, the gas stream consisted of dry air (dew point $<-60^{\circ} \mathrm{C}$ ) with an iodine concentration of $50 \mathrm{ppmv}$. Initial sample weight was $2.2271 \mathrm{~g}$. The weight change of the sample over time is shown in Fig. 5 (blue line). Following the test, the iodine-loaded aerogel sample was analyzed by neutron activation and found to contain $27.24 \mathrm{wt} \% \pm 0.10 \mathrm{wt} \%$ iodine on a total sample (aerogel + iodine) basis. This would indicate a weight gain due to iodine of about $37.4 \%$ based on the initial weight of aerogel, which may be compared to the macro-TGA measured value of $29.3 \%$ at a run time of $176.5 \mathrm{~h}$ - the time when the sample appeared to be saturated. At the conditions of the run, the rate at which the iodine was delivered by the feed gas stream was about $6 \mathrm{mg} / \mathrm{min}$, implying a total iodine delivery of $64.1 \mathrm{~g}$. Based on the macro-TGA weight gain, the amount of iodine sorbed by the sample was $0.653 \mathrm{~g}$. Therefore, over the course of the adsorption test, uptake of iodine by the thin bed of aerogel resulted in an average change in the gas phase concentration of iodine across the bed of around $1 \%$. This 
is a minor departure from the assumptions used in modeling thin bed experiments, specifically that there is a negligible change in gas composition across the bed.

In the third phase test, the gas stream was humidified air with a dew point of $0^{\circ} \mathrm{C}$ and an iodine concentration of 50 ppmv. Weight change of the sample over time also is shown in Fig. 5 (red line) to permit comparison with loading of iodine from dry air. As shown, the ultimate weight gain was nearly the same in both experiments. The weight gain is presumed to be due entirely to adsorption of iodine because prior tests indicated that the aerogel does not adsorb water. However, a reduced rate of iodine uptake is indicated when water vapor is present. The reason for this reduction is unclear, but it is speculated to be the result of conversion of part of the iodine to another form (e.g., hydrogen iodide). In both cases, purging the sample with dry iodine-free air resulted in some weight loss, on the order of $2 \mathrm{wt} \%$. Neutron activation analysis of the aerogel collected following this run has not yet been completed.

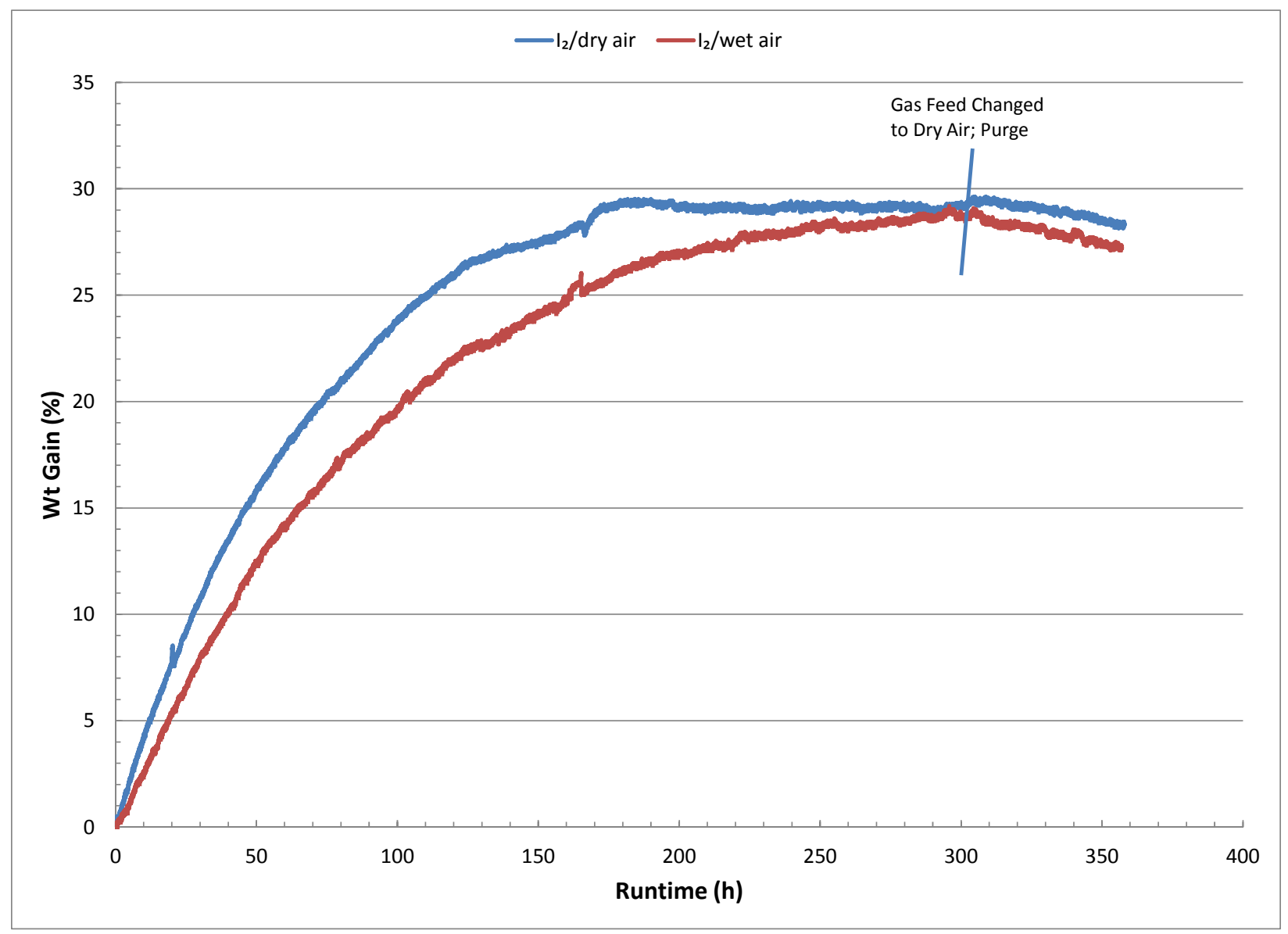

Fig. 5. Fractional change in aerogel weight during iodine uptake from air streams containing 50 ppmv $I_{2}$ and water dew points of either $<-60^{\circ} \mathrm{C}$ or $0^{\circ} \mathrm{C}$.

\section{CONCLUSIONS AND RECOMMENDATIONS}

The co-adsorption of iodine and water on silver-functionalized silica aerogel was evaluated using research quantities of the aerogel prepared at PNNL. A macro-TGA was used to measure weight changes in a thin 
bed of the aerogel as air streams containing moisture and/or iodine flowed through the bed. In all tests the total gas flow was adjusted to achieve a velocity of $10 \mathrm{~m} / \mathrm{min}$ through the bed.

Initial heating of the aerogel sample to $150^{\circ} \mathrm{C}$ in dry air (dew point $<-60^{\circ} \mathrm{C}$ ) resulted in weight loss. Because subsequent phases of the tests indicated that the aerogel did not sorb water, the weight loss was speculated to be caused by volatilization of material that may have been used in the manufacture of the aerogel.

In tests using humidified air streams with dew points between $-60^{\circ} \mathrm{C}$ and $+10^{\circ} \mathrm{C}$, the aerogel did not adsorb water at test temperatures of either $75^{\circ} \mathrm{C}$ or $150^{\circ} \mathrm{C}$. Because water alone was not adsorbed, tests were performed to ascertain whether iodine sorption varied between cases when nearly no water was present in the gas stream and when water was present.

In one experiment, the gas stream consisted of dry air (dew point $<-60^{\circ} \mathrm{C}$ ) with an iodine concentration of $50 \mathrm{ppmv}$. In the other experiment, the gas stream consisted of air having a water dew point of $0^{\circ} \mathrm{C}$ and an iodine concentration of $50 \mathrm{ppmv}$. The ultimate weight gain was nearly the same in both experiments and was presumed to be due entirely to adsorption of iodine. However, a reduced rate of iodine uptake is indicated when water vapor is present. The reason for this is unclear. In both cases, purging the sample with dry, iodine-free air resulted in some weight loss, on the order of $2 \mathrm{wt} \%$.

It is recommended that additional tests be performed to ascertain if the aerogel sorbs water at low temperatures, such as $25^{\circ} \mathrm{C}$ - this would help to determine if a manufacturing reagent is volatilized when raising the sample to iodine sorption temperatures $\left(\right.$ i.e., $\left.150^{\circ} \mathrm{C}\right)$. Alternatively, the off-gas released upon heating could be condensed and analyzed. The gas phase chemistry of the iodine-water system should be reviewed to ascertain if iodine species less reactive with silver than molecular iodine are present; this could explain the reduced sorption rates when water is present. Further evaluation of the desorption is recommended, especially to determine how raising the temperature would affect desorption.

\section{REFERENCES}

1. B. B. Spencer, S. H. Bruffey, J. F. Walker, Jr., and R. T. Jubin, Integrated Iodine and Water Coadsorption Tests, ORNL/LTR-2014/472, also FCRD-SWF-2014-000034, UT-Battelle LLC, Oak Ridge National Laboratory, Oak Ridge, Tenn., 30-September-2014 (Official Use Only-Export Controlled Information).

2. J. Matyáš and R. K. Engler, Assessment of Methods to Consolidate Iodine-Loaded SilverFunctionalized Silica Aerogel, FCRD-SWF-2013-000589, also PNNL-22874, Pacific Northwest National Laboratory, September 2013.

3. J. Matyáš, Silver-Functionalized Silica Aerogel for Testing at ORNL, FCRD-MRWD-2015-000697, Pacific Northwest National Laboratory, 18-December-2014.

4. B. B. Spencer, S. H. Bruffey, J. F. Walker, Jr., and R. T. Jubin, Study of Iodine and Water Coadsorption on Thin Beds of 3AMS and AgZ, FCRD-SWF-2013-000116, also ORNL/LTR-2013/103, UT-Battelle LLC, Oak Ridge National Laboratory, Oak Ridge, Tenn., 15-March-2013.

5. R. T. Jubin, Report of the FY11 Activities of the Off-Gas Sigma Team, FCRD-SWF-2011-000306, Oak Ridge National Laboratory, September 2011. 